ETO: 791.221 .5

DOI: $10.19090 / \mathrm{hk} .2016 .1 .1-15$

ORIGINAL SCIENTIFIC PAPER

\title{
GELENCSÉR Gábor
}

Eötvös Loránd Tudományegyetem, Bölcsészettudományi Kar

Müvészetelméleti és Médiakutatási Intézet, Filmtudomány Tanszék

Budapest

gelencser.gabor@btk.elte.hu

\section{NÉPSZERÜ FILMKULTÚRA AZ ÁLLAMSZOCIALIZMUS KORÁBAN} A magyar bünügyi film példája

\section{Popular Film Culture in the Era of State Socialism}

An example of Hungarian crime films

\section{Popularna filmska kultura u doba državnog socijalizma Na primeru mađarskog kriminalističkog filma}

Az 1945 utáni időszak magyar filmtörténetét elsősorban a szerzői film paradigmájában szokás megfogalmazni. A népszerü (populáris vagy műfaji) filmgyártás helyzete az államszocializmus 1948 és 1989 közötti időszakában ellentmondásos, s ennek hatása egészen máig érezhető. A tanulmány a népszerü filmkultúra helyzetének általános áttekintése után az ellentmondás okait és következményeit a bünügyi film negyventételes korpuszának példáján vizsgálja. Mindez részben gazdagíthatja a korszak filmtörténetének leírását, részben segítheti a kortárs magyar filmművészet helyzetének értelmezését, amelyben a népszerü filmkultúra és benne a bünügyi film helyzete - az 1989 után megváltozott társadalmi és politikai feltételrendszer ellenére - továbbra is ellentmondásos.

Kulcsszavak: magyar filmtörténet, népszerü filmkultúra, az államszocializmus korszaka, a bünügyi film müfaja.

\section{1.}

A magyar népszerü film ellentmondásos helyzetét jól reprezentálja a bünügyi film müfajcsaládja, amely nem tartozik az 1945 utáni időszak legnagyobb csoportjába - ezt a rangot továbbra is a vígjáték őrzi -, ugyanakkor azt sem mondhatjuk, hogy teljességgel hiányozna a palettáról, szemben például a gyakor- 
latilag nem létező sci-fivel vagy horrorral. Szórványosan már az 1945 előtti korszakban is felbukkan, ám igen sok kívánnivalót hagy maga után (vö. Lakatos 2013). Egyfelől tehát mint a korszakban számarányát tekintve átlagos, másfelől mint már az 1945 előtti időszakban is ellentmondásos helyzetü müfaj megfelelő példát kínál az áttekintéshez. Reprezentativitását növeli, hogy a müfajcsalád több tagja (krimi, kémfilm, thriller, film noir, gengszterfilm) megtalálható a magyar filmben - igaz, arányuk sokatmondó: a legtöbb magyar bűnügyi film a krimik, míg a legkevesebb a gengszterfilmek körébe sorolható.

A népszerü film 1945 utáni helyzetének általános áttekintése után veszem sorra az államszocializmus korszakának bünügyi zsánerü alkotásait. A negyventételes korpuszt a müfajcsaládon belüli sajátosságaik szerint csoportosítom, majd ez alapján vonok le következtetéseket az 1948 és 1989 közötti időszak egyes filmtörténeti periódusaira, illetve általánosan az államszocializmus korának népszerü filmjére vonatkozóan. Végül a népszerü film ellentmondásos helyzetét két, kivételesnek mondható bünügyi film példáján mutatom be.

\section{2.}

A népszerü film második világháborút követő időszakának helyzetéről általánosan kijelenthetjük, hogy az 1945 elöttihez képest e filmtípus elveszti korábbi szerepét. Készülnek természetesen ilyen filmek 1945 után is, ám ezeknek előbb a filmtörténeti súlya, majd később a száma is drámaian megcsappan. A népszerü film, szemben eredeti szerepével, a ,problémátlan” szórakoztatás helyett politikai, ideológiai és müvészeti problémát jelent; folyamatos vitára, reflexióra indítja a kultúrpolitikusokat, a kritikusokat és a filmeseket egyaránt. Mi ennek az oka? Mi a magyarázat arra, hogy a szocialista táboron belül Magyarországon különösen nehéz a népszerü filmek sorsa. A szocialista országok kultúrpolitikájának a tömegkultúra iránt táplált „nyilvánvaló és közvetlenül is érzékelhető ellenszenvén" (Kovács 1989,29) túl mennyiben sajátos a magyarországi helyzet?

A szokatlanul éles és elsősorban a népszerü filmet érintő cezúra oka az 1945 előtti filmművészeti hagyományban keresendő, amely - beleértve a tízes évek néma- és a harmincas évek hangosfilmkorszakát - elsősorban piaci alapon szerveződik, és müfaji filmeket gyárt. Ez a hagyomány összefonódik a korabeli rezsim politikájával, ízlésével és értékrendjével, amelyet a filmesek még müfaji alapon, így a második világháború kitörése után népszerüvé váló melodrámákban is kevéssé képesek kritikusan ábrázolni. Az 1931 és 1945 közötti időszak paradigmatikus szórakoztató filmes müfaja nem véletlenül a vígjáték, azon belül is a könnyü boldogulás vágyálmát megfogalmazó glamour komédia (vö. Balogh-Király 2000). 
A rövid koalíciós átmenetet követően 1948-ban kialakuló szovjet mintájú totalitárius egypártrendszer minden elemében az 1945 előtti korszakkal szemben határozza meg magát. 1948 után a baloldali diktatúra az előző rezsim politikáján túl annak kulturális teljesítményét is negligálja, beleértve a piaci alapon szerveződő, azaz kapitalista, a társadalomelemzés helyett a szórakoztatásnak „behódoló”, az uralkodó osztály igényeit és ideológiáját kiszolgáló filmgyártást. Mindennek következtében a háború után a magyar népszerü filmnek nincs legitim hagyománya, illetve a létező hagyomány folytathatatlannak bizonyul. Nem tekinthetô túlzott leegyszerüsítésnek a magyar populáris film kiváló kutatójának, Király Jenőnek egy interjúban megfogalmazott sommás megállapítása, miszerint: „A régi magyar film tisztán tömegkultúra volt, olyan homogén módon tömegkultúra volt, mint amilyen módon nem tömegkultúra az 1945 utáni magyar film" (Váradi-Kovács 1995, 47). De lássunk ugyanerről egy újabb, körültekintőbb és részletesebb megfogalmazást!

A szocialista kultúrpolitika a két világháború közötti magyar filmgyártás örökségét nem vállalta, részben ideológiai okokból, részben pedig a müfajisággal, illetve általában a popularitással szembeni ellenérzései miatt. A müfajfilmek ugyan nem tüntek el teljesen, de egészen a nyolcvanas évekig gyanúsnak számítottak azon müvek, amelyek nem közvetítettek valamiféle „üzenetet”, nem volt „társadalmi mondanivalójuk”, nem szolgáltak ,tanulsággal”, hanem csupán szórakoztatni kívántak (Pápai-Varga 2010, 17).

A második világháború utáni időszak a populáris film tekintetében tehát az előző korszak inverzeként írható le, s e változásban meghatározó szerepet játszik a politikai rezsimek szintén inverz átalakulása a jobboldaliból baloldali diktatúrába. Ám a baloldali rezsim (szovjet mintára) a maga propagandisztikus céljaira igyekszik a populáris film kódrendszerét is mozgósítani, méghozzá jóval erőteljesebben, mint a korábbi jobboldali rezsim ideológiai irányzata, az ún. népi film (vö. Vajdovich 2013). Az ötvenes évek szocialista realista filmjeiben ezért alkalmanként felismerhetők müfaji vonások, a narratív struktúrában pedig - meglepő módon - a klasszikus hollywoodi típusú elbeszélésmód sémái, természetesen megfelelő ideológiai ágensek közremüködésével. A leggyakoribb múfaj továbbra is a vígjáték (pl. Keleti Márton: Dalolva szép az élet, 1950; Ifjú szivvel, 1953), sőt operettadaptáció is születik (Gertler Viktor: Állami áruház, 1952), a termelési filmek szabotázsmotívuma pedig, ahogy erre a korszak bünügyi filmjeinek áttekintésekor még visszatérek, a bünügyi film múfaji elemeit mozgósítja. Ám a szocialista realista korszak nem a müfajba 
kódolt archetípusok segítségével (vö. Király 1998), közvetetten fogalmazza meg a maga ideologikus társadalmi jelentését, hanem ezt közvetlenül, direkt és nyílt propagandisztikus céllal teszi, s ezzel ahelyett, hogy termékeny módon alkalmazná, inkább kompromittálja a múfajiságot. A magyar népszerü film 1945 utáni ellentmondásos helyzetében a ' 45 elötti megtagadott hagyomány mellett a '45 utáni kompromittált hagyomány is szerepet játszik. ${ }^{1}$

Az ideológiai alapú tömegkultúra-ellenesség, illetve az ideológia direkt megfogalmazásának propagandisztikus igénye azonban nemcsak az új hatalompolitikai gyakorlat következménye, a hatvanas évektől ezt támogatja alkotói oldalról a modernista szerzői film politikája és poétikája is. S ez a körülmény megint csak jóval árnyaltabbá teszi a magyar népszerü film helyzetét, semmint hogy azt pusztán a politikai cenzúra áldozatának tekintsük.

Az 1948 és 1953 közötti szocialista realizmus, majd az ezt követő hosszú átmeneti periódus után, 1963-ban Magyarországon is kibontakozik az európai modernizmushoz mérhető új hullám. Ennek indulása szorosan kötődik az 1956-os forradalmat leverö, majd saját rendszerét rendkívül gyorsan és eredményesen konszolidáló Kádár János nevéhez. A hatvanas évek Magyarországon a sikertelen forradalom után a sikeres reformok ígéretét hozza, a reformhangulat, a bizakodás kialakításában pedig nagy szerepe van a kultúrának, azon belül az ekkor a figyelem középpontjába kerülö filmnek. A kultúrpolitikai enyhülés kedvez az új hullám kialakulásának - az új hullám kialakulása bizonyítja a kádári konszolidáció hatékonyságát. De a kultúrpolitikai enyhülés bizonyos mértékig kedvez a populáris filmnek is, amennyiben lemond a voluntarista ideológiai nevelés rossz emlékü hagyományáról, illetve azt korszerübb eszközökkel igyekszik megvalósítani - egyetértésben a filmesekkel. Az egymásra utaltság és az érdekek találkozása hozza létre a hatvanas években a magyar film történelmi virágkorát, s ebben a sikerben a kánonképző szerzői film mellett ekkor még a populáris filmnek is jut valamennyi szerep.

A hangsúly azonban egyre jobban a szerzői filmre kerül: a magyar új hullámot, mint mindenütt Európában, a modern szerzői film hozza létre. A fiatal új hullámos nemzedék ad arcot a mozgalomnak, az új hullámos stílus képviseli a progressziót politikai és poétikai értelemben egyaránt. Az újabb nemzedék a szerzői film politikája mellett kötelezi el magát, a reformista kultúrpolitika pedig a szerzői filmben rejlő politikai progressziót támogatja. A népszerü film ideológiailag továbbra sem támogatott filmtípus, ami pedig támogatható volna,

\footnotetext{
${ }^{1}$ Itt köszönöm meg Pápai Zsolt értékes megjegyzéseit, amelyeket elsősorban az ötvenes évekről és a Dögkeselyüről szóló részletekbe építettem be.
} 
az a direkt propagandisztikus szándék miatt vagy ellentmondásos eredményt hoz (ahogy ezt a bünügyi filmek többsége mutatja), vagy lemond a mủfajba kódolt ideológiai jelentésről (mint néhány, direkt ideológiai utalást nélkülöző krimi). Ezzel szemben a szerzői film sikeresen tudja ötvözni a társadalmi progressziót a mủvészi innovációval, aminek következtében a hatvanas évek végére a szerzői és a populáris film egyensúlya felbomlik, $\mathrm{s}$ a hetvenes évektől nemcsak a szerzői film hegemóniája erősödik meg a magyar filmben, hanem a populáris film addigi, számát és közönségsikerét tekintve legalábbis érzékelhető jelenléte is megrendül, és a filmtípus kisebbségbe szorul.

A hatvanas évek végi reformok a kultúrpolitika terén még engedményt tesznek a népszerü (film)kultúrának, ám a reformok lefékezésével ez a szándék is elhal, illetve csak bátortalan módon, óvatoskodva érvényesül. A reformista elképzelés szerint a müvészet egyszerre feleljen meg az ideológiai elvárásoknak (társadalmi funkció) és a tömegigényeknek (szórakoztató funkció). A különös az, hogy ez az elképzelés a népszerü filmben egyáltalán nem megvalósíthatatlan. Sőt, a tömegkultúra épp e két erénnyel rendelkezik: a müfajba kódolt archetipikus történetek sokak számára érthető és átélhető ideológiai jelentést fogalmaznak meg. Csakhogy a kultúrpolitika mindennél jobban tart a valóban releváns, egyértelmű igazságok kimondásától, s főképp annak populáris formában történő, népszerü és közérthető megfogalmazásától (a populáris kódrendszer propagandisztikus célú felhasználásának ideje pedig ekkorra már lejárt). A kádári kultúrpolitika cinizmusára vall, hogy a szerzői film értelmiségi beszédmódjában bizonyos határon belül megengedi a kritikát, hiszen ez a filmtípus csupán egy szűk réteghez jut el. A tömegeket elérő populáris kultúra regiszterében azonban mindez már felforgató erejü lehet, s így valós társadalmi veszélyt jelenthet.

Hasonlóan ellentmondásos helyzetbe kormányozza magát az a néhány filmes, aki eltökélten müfaji filmeket próbál forgatni, sőt új müfaj létrehozásán fáradozik. Király Jenő a western mintájára megalkotott eastern példáján mutatja be, hogyan fut zátonyra ez a kísérlet, de következtetése a vizsgált müfaj határain túl is érvényes. A „double bind” fogalmával leírt jelenség szerint az alkotók nem merik vállalni a müfaji film leegyszerüsítő, mitizáló sémáit, $\mathrm{s}$ a történetbe az analitikus művészfilm szempontját is beleszövik, miáltal műveik az egymást kioltó formák következményeként sem müfaji, sem szerzői filmként nem értelmezhetők, illetve élvezhetők (Király 1981).

A hetvenes évektől felborult egyensúlyi állapot nemcsak a következő két évtized, azaz a rendszerváltozásig terjedő időszak filmtörténetét határozza meg, 
hanem hatással van a kortárs magyar filmre is. A nehéz örökséget és annak következményét foglalja össze egy 1995-ben született esszé. A népszerü filmkultúra 1945 és 1989 közötti helyzetének általános bemutatása végén azért is érdemes hosszabban idéznünk ebből az írásból, hogy a belöle áradó gunyoros és indulatos hangra is felfigyeljünk, amely a hetvenes évektől egyoldalúvá váló szerzői hegemónia káros hatását teszi szóvá.

Ilyen-olyan okból a magyar népszerü filmgyártás, amely a harmincasnegyvenes években világszínvonalú volt, elsorvadt, és helyét átvette a szerzői film. Ennek hegemóniája azóta is tart, és filmrendező-generációk nőttek fel abban a tudatban, hogy szerzői és dokumentumfilmen kívül semmi mással nem érdemes foglalkozni. Márpedig vagy húsz éve ennek a (hamis) tudatnak a csődjét éli a magyar film, csak egy ideig ezt a csődöt elfedte a politika. Senki sem vette észre, hogy igazi szerzői film mindig, mindenütt egy már erős népszerü filmipar háttere előtt alakult ki. Így volt ez az olasz neorealizmus és a francia új hullám esetében is. Sőt, a hatvanas évek magyar új hulláma mögött is ott volt egy erős tömegfilmes hagyomány, amely az ötvenes években - bármilyen furcsa -, folytatódott, s föleg Keleti Márton jóvoltából a hatvanas években még új erőre is kapott. Ez a hagyomány azonban teljesen elhalt a hetvenes években, s eltekintve egy-két kísérlettől, azóta is tetszhalott állapotban van. A jelenlegi magyar filmrendezők abban nőttek föl, hogy inkább a közönséget kell átnevelni a müvészfilmekre. Csakhogy ez súlyos tévedés. A magyar filmgyártás nem állhat talpra, amíg ez a felfogás uralkodik, és nem éled újra a magyar népszerü film. Nem a mélán lirizáló müvészettől kell várni, hogy tömegeket vonzzon a moziba, hanem meg kell teremteni a magyar filmgyártás teljes spektrumát, amelynek a szerzői film csupán egy része. A magyar nézőt a népszerü magyar filmnek kell visszacsalogatnia a moziba, nem a lírai-történelmi-politikai ömlengésnek és értekezésnek (Kovács 1995, 5).

3.

A népszerü filmkultúra 1945 utáni fent vázolt általános helyzetét jól szemlélteti a bünügyi film konkrét müfaja. Ahogy erre már röviden utaltam, a bünügyi film - az elnyühetetlen vígjáték mellett - már az ötvenes években is jelen van, ám igen kompromittálódott helyzetben. Erre a körülményre azért érdemes részletesebben kitérni, mivel igen mély nyomot hagy a későbbi évek bünügyi zsánerén. 
A szocialista realista filmek önálló müfajt is létrehoznak: a termelési film foglalja magában mindazokat a konfliktus- és karaktertípusokat, mutatja be azt a környezetet, amelyben a kommunista ideológia a leghatékonyabban képes kifejezni a maga propagandisztikus agitációját. Ezekben a filmekben a „munka frontján", azaz üzemi környezetben folyik a harc a végső győzelemért a haladó kommunisták és konzervatív reakciósok között. A bünös múltú reakciósok szabotálással igyekeznek akadályozni a fejlődést, s ennek során büncselekménytől, akár gyilkosságtól sem riadnak vissza, amit természetesen a kommunista hatalom éber rendőrsége leleplez. A bünügyi film müfaji sémái, sőt a műfajcsaládon belül a thriller bizonyos elemei igen fontos dramaturgiai szerepet kapnak a termelési filmekben, így a müfajt megalapozó Tüzben (Apáthi Imre, 1948), a kollektivizmus szellemében a „Magyar Filmgyártó Nemzeti vállalat rendezöi és dramaturgiai munkaközössége" által jegyzett Gyarmat a föld alattban (1951), legkiforrottabb formájában pedig Máriássy Félix Teljes gözzel címü 1951-es munkájában. A termelési filmek bünügyi szubzsánere ezzel a - leginkább a karaktereken nyomot hagyó - politikai tehertétellel él tovább a következő évtizedekben.

A direkt propagandisztikus jelentés szolgálatába állított bünügyi film, a „szocialista krimi” karaktersémáját a bün(ös) és a bünüldöző ideológiai minemüsége határozza meg (vö. Koltai 1986, Mecseki). Eszerint egyrészt a szocializmus világában nincs jelen a bün: a bünelkövető külföldről érkezik, az ellenséges kapitalista világ ügynöke vagy 1956-os magyar disszidens. Másrészt a szocializmus világában nincs jelen a magánnyomozó: a bűnüldözés feladatát szervezett és kollektív formában állami testület látja el. E két komplementer ideológiai alapvetésnek kétféle következménye lesz. Az egyik a társadalmi, politikai és ideológiai jelentés közvetlen és propagandisztikus megjelenése a karakterekben. Voltaképpen ennek köszönhetően maradhatnak fenn a müfaj egyéb klasszikus, ideológiamentes elemei, mint a lopás, zsarolás, gyilkosság, illetve a nyomozás. A bünügyi esemény propagandisztikus kontextusát tehát alapvetően a karakterek és motivációik teremtik meg. A másik következmény már áthatóbban és alapvetően érinti a müfajt. Az egyoldalúan átpolitizált bünfogalom ugyanis felszámolja a bün metafizikus természetét (vö. Bényei 2000), a bünüldözés kollektivizálása pedig az individuális érintettség jelentéskörét vonja ki a történetből. Ebből ered az a gyakori nézői érzés, hogy a magyar bünügyi film provinciális, s jóval inkább a múfaj paródiája, semmint a világ és az ember sötét oldalát feltáró drámai alkotás. Politikai motiváció, provincializmus, paródia - e három „p” köré csoportosíthatók az államszocializmus korszakának bünügyi filmjei. 
Lássuk tehát a szocialista realizmus korszakában megalapozott, negyven filmből álló korpusz jellegzetesebb darabjait! Melyik csoportba tartoznak, illetve hova sorolhatók be leginkább (hiszen a csoportok között átfedések is elképzelhetők), valamint akadnak-e a fenti osztályozásból kiszoruló kivételek?

A propagandisztikus ideológiai jegyekkel motivált karakterek jószerével valamennyi bünügyi filmben felismerhetők. A szocialista realizmus korszakában ez egészen nyílt és sematikus módon jelenik meg: a bűnös az előző rendszer kiszolgálója, volt nyilas vagy legalábbis arisztokrata, esetleg értelmiségi, mindenesetre a reakciós erők szekértolója. Vele szemben a rendőrség kötelékében tevékenykedő nyomozó a haladók csoportjának segítője, támasza. Ez a séma, mint látni fogjuk, egészen a rendszerváltozásig felismerhető marad, legfőbb bizonyítékaként a népszerü filmkultúrát átható direkt propaganda jelenlétének.

A szocialista realizmus sematikus hagyományát legdirektebb módon Gertler Viktor Egy ember, aki nincs címü 1963-as filmje folytatja, de a bünöző reakciós beállítottsága vagy külföldi kapcsolata még számos későbbi filmben előkerül. Az alvilág professzora (Szemes Mihály, 1969) alapvetően magyar érdekeltségü története egy nyugatnémet milliomos kisfiának elrablásával indul, s még az olyan önreflektív, ily módon esszenciális kriminarratívában is ott a nyugati motívum, mint az Ártatlan gyilkosok (Várkonyi Zoltán, 1973): a bünügyi müfajból szakdolgozó két bölcsész egy Hollywoodból hazatérö magyar származású rendezőt hív ki tragikus végkifejletü szellemi párbajra.

A bünügyi motívumokat alkalmazó történelmi filmekben a megfelelően kiválasztott korszakból fakad a politikailag motivált bün(ös). Matuska Szilveszter 1931-es biatorbágyi merényletét, majd az az alapján provokált kommunistaüldözést a politikai krimik múfaji szabályai szerint két film is feldolgozza az államszocializmus korszakában: Várkonyi Zoltán Merénylete 1959-ben és Simó Sándor Viaduktja 1982-ben; az előbbi inkább a pszichothriller, az utóbbi az akciófilm müfaji sémáit mozgósítja. A Hekus lettem (Fejér Tamás, 1972) második világháború után szolgálatba álló újonc rendőrei a reakciósokat reprezentáló feketézők, maffiózók és pénzhamisítók ellen veszik fel a harcot. A Galgóczi Erzsébet azonos címü regénye nyomán forgatott $A$ közös bün (Mihályfi Imre, 1977) az 1956-os forradalmat követő zavaros helyzetet vizsgálja egy gyilkosságba véletlenül belekeveredő család sorsában. Hasonló mondható el a társadalmi drámákban megjelenő bünügyek ideológiai hátteréről. A Fejes Endre novellája alapján készült, moziban is forgalmazott $J o ́$ estét nyár, jó estét szerelem címü tévéfilm (Szőnyi G. Sándor, 1971) lélektani drámájában fontos motívum a gyilkossá váló szélhámos „nyugati diplomata" mimikrije, illetve a gazdag világ ígéretével becsapott lányok és családjuk 
társadalmi és gazdasági orientációja, értékrendje. S a karakterekben fellelhető direkt politikai motívumkincs jelenléte a rendszerváltozásig kitart: Gazdag Gyula Túsztörténetének (1988) két fiatal föhőse a helyi katonai parancsnok fia - ez fegyverhez jutásukban fontos mozzanat -, akik sikertelen akciójukkal nyugatra próbálnak szökni. Tímár Péter szintén a rendszerváltozás előestéjén született, müfaji kuriózumnak számító pszichothrillerében, a Mielött befejezi röptét a denevérben (1988) pedig az antagonista nemcsak pedofil homoszexuális, hanem ráadásul még rendörnyomozó is - igaz, ennek a körülménynek a történet alakításában már nincs érdemi szerepe.

Tekintélyes tematikus csoportot alkotnak a kémfilmek, mivel bennük a politikai és az ideológiai motivációk magától értetődően kaphatnak helyet, így a kémkedő reakciósok és nyugati megbízóik üzelmei jóval indokoltabbak. A történelmi kémfilm itt is a korszakba „kódolja” az elkövetőt (Bán Róbert: Dóra jelenti, 1978), ám a jóval gyakoribb jelen idejü történetekben, ahol értelemszerüen békebeli ipari kémkedés zajlik, már nyilvánvalóbb a politikai motívum (Várkonyi Zoltán: Foto Háber, 1963; Nádasy László: Fény a redőny mögött, 1965; Oláh Gábor: A múmia közbeszól, 1967; Keleti Márton: Fuss, hogy utolérjenek, 1972; Mészáros Gyula: A néma dosszié, 1977). Nyugati kémkedés a szocialista Magyarország müszaki teljesítményeiért - ezt már a hatvanas-hetvenes években sem lehetett komolyan venni, aminek következtében e kémtörténetek átfedésbe kerülnek a provinciális és/vagy parodisztikus bünügyi filmek csoportjával. Egyetlen kivétel - nem véletlenül - a Foto Háber, amely a rendőr karakterét határozottan individualizálja és a kalandromantika eszköztárával is gazdagítja.

A provinciális bünügyi filmek között olyanokat találunk, mint a zsebtolvajt az utasok segítségével leleplező Mindenki ártatlan? (Palásthy György, 1961), a családi konfliktust egy gázolási esettel „súlyosbító” Húsz évre egymástól (Fehér Imre, 1962) vagy a notórius házasságszédelgőt jó útra térítő Özvegy menyasszonyok (Gertler Viktor, 1964). Ezekben egyrészt az a biztató jelentés fogalmazódik meg, hogy komoly bün nincs jelen a szocialista társadalomban, ám ha mégis előfordul valami jelentéktelen kihágás, azt az öntudatos civil kollektíva - a rendőrség paternalista támogatásával - együttes erővel leplezi le. Sokkal üdítőbb, amikor ezt a narratívát már maguk az alkotók sem veszik komolyan, és bünügyi paródiát forgatnak, ahogy az ipari kémkedésről szóló filmek többségében, vagy olyan, már címükkel is sokatmondó munkákban, mint az Emberrablás magyar módra (Várkonyi Zoltán, 1972) és az Illatos út a semmibe (Magyar József, 1973). Révész György Az oroszlán ugrani készül (1969) címủ James Bond-paródiája pedig már-már abszurdba hajlik, hiszen 
olyan népszerủ sorozatot állít célkeresztbe, amit a közönség annak idején politikai okokból nem láthatott a hazai mozikban.

Az oroszlán ugrani készül átvezet az ,importált hösöket” felléptető bünügyi filmek csoportjába. Ennek első darabja, a Kojak Budapesten (Szalkai Sándor, 1980) egyúttal a provinciális filmek körét is gazdagítja: az Amerikából hazatérő, magyar származású, egykor Kócsag néven tevékenykedő világhírü nyomozó olyan szövevényes bünténysorozatot tár fel, amelynek minden láncszemében a müködésképtelen magyarországi infrastruktúra „lepleződik le”. Sikeresebb, a rendszerváltozáson átívelő széria füződik a „magyar Piedonét” megformáló, később rendezővé avanzsáló Bujtor István nevéhez (Mészáros Gyula: A Pogány Madonna, 1980; Szőnyi G. Sándor: Csak semmi pánik, 1982; Bujtor István: Az elvarázsolt dollár, 1985; Hamis a baba, 1991). Az „importált hősök” azonban - ahogyan az e címen megjelenő tanulmány kifejti - épp a társadalmi jelentést vonják ki a filmekböl, s ezzel általában is rámutatnak a magyar bünügyi filmek legföbb deficitjére.

A tömegfilm üzenete ugyanis maga a társadalom, s így a tömegfilmek hőseinek adekvát módon kell felszívniuk a megfelelő társadalmi jegyeket. Ha ez nem történik meg, vagy ha a hős egy másik kultúra, egy másik kollektíva jegyeit, értékeit, prioritását hordozza, attól még lehet szórakoztató, de nem töltheti be a konkrét társadalomhoz kötődő „szocializáló” funkcióját (Réz 1984, 264).

Ezt a hiányt nem pótolják a direkt propagandisztikus motívumoktól mentes bünügyi filmek sem - mert azért ilyenek is akadnak, igaz, jóval kisebb számban: a teljes müfaji korpusz alig egynegyedét teszik ki. E filmek ugyanis azon az áron tudják kiszorítani a propagandisztikus ideológiát, hogy magát a müfajba kódolt ideológiát is minimalizálják vagy felszámolják, a történetet elszigetelik a valós tértől és időtől, a bünügyi narratívát magának a büntettnek és a nyomozásnak a bemutatására, a szereplők motivációját pedig a lélektanukra korlátozzák. A szükítés hozza létre a bünügyi müfajcsalád Magyarországon ritka almüfajait: disztópiát (Szinetár Miklós: Az erőd, 1978), viktimológiai krimit (Dobray György: Az áldozat, 1979), heist filmet (Fábry Péter: Nyom nélkül, 1981). S ide sorolhatók a népszerü adaptációk, mint a Rejtő Jenő Vesztegzár a Grand Hotelben címủ regényéből készült Meztelen diplomata (Palásthy György, 1963), vagy ugyanebből az évböl egy olyan különlegesség, mint az angol regény alapján amerikai rendező közremüködésével a Metro Goldwyn Mayer koprodukciójában forgatott Az aranyfej (Richard Thorpe, 1963). S végül a kisebbségi csoporton belül is kisebbséget képviselő „tiszta” krimik, a müfaj 
ma is élvezhetö, ám meglehetősen súlytalan, filmtörténetileg kevéssé reprezentatív darabjai a következők: Hintsch György: Kártyavár (1967), Bácskai Lauró István: A hamis Izabella (1968), Bán Róbert: A gyilkos a házban van (1970), Bacsó Péter: A svéd, akinek nyoma veszett (1980).

\section{4.}

Az államszocializmus korában a magyar bünügyi filmek meghatározó többsége a szocialista realizmus termelési filmjeinek szabotázsmotívumában kifejlesztett, a bünt a reakciósok, míg a bünüldözést a haladók csoportjához társító $\mathrm{s}$ ezzel propagandisztikus célzatú ideológiai jelentést fogalmaz meg. Főként a bün motivációjának és a bünös karakterének leegyszerüsítő, sematikus ábrázolása hozza ellentmondásos helyzetbe a müfajt, amellyel megfosztja eredeti és releváns ideológiai potenciájától, s önleleplező, paródiába illő helyzetbe hozza. A magyar bünügyi filmek tehát a müfaj általános vonásának megfelelően ideologikusak - csakhogy az ideológia nem involválódik a múfaj kódrendszerébe, hanem a propaganda külsőleges ,védjegyeként” kerül a müre, mintegy a kultúrpolitika ideológiai pecsétjeként.

A propagandisztikus motívumok átható jelenlétét bizonyítják azok a filmek, amelyek számos ponton el tudnak szakadni a szocialista realizmus korszakának sémáitól, s ezzel a mủfaj sajátos kódrendszerén belül fejezik ki ideológiai jelentésüket. Befejezésül két ilyen filmre szeretnék kitérni, amelyek hozzávetőlegesen keretezik az itt vizsgált negyventételes korpuszt.

Az első Gertler Viktor 1955-ös, azaz a szocialista realizmust követő filmmủvészeti megújulás évében készült Gázolása, a második András Ferenc Dögkeselyüje 1982-ből. Mindkettő a bünügyi film családján belül a filmtörténetileg különösen rangos, müfajként és stílusként egyaránt megragadható film noirok körébe tartozik, amilyenre példát csak az 1945 elötti korszakban találunk. A két film szorosabban vett müfaja is kivételes, és még számos további hasonló értékes vonásuk van, például a lélektanilag egyénített, sokrétü karakterek, a városi környezet kreatív bevonása a történet bonyolításába, a kifejező hangulatfestő elemek. A Gázolásban kiemelkedő a csábító femme fatale karakter és az érzelmi befolyás alatt vergődő protagonista viszonyának összetett ábrázolása, valamint a filmnoir-narratívára jellemző in medias res szerkezet. A Dögkeselyüben erős női karakter nem található, a főszereplő rajza azonban annál erőteljesebb: a bizonytalan egzisztenciájú férfit egy egyszerü lopás mozdítja ki mindennapos rutinjából, s avatja önbíráskodó igazságosztóvá, aki egyedül küzd a város dzsungelében, $\mathrm{s}$ jut el törvénykívüli akciójának konzekvenciájáig: az önpusztításig. Erős műfaji vonások, több alműfaj markáns jelenléte (melodrá- 
ma, thriller, western), színvonalas kivitelezés - és mégis, mindkét film magán hordozza a szocialista realizmus bűnügyi sémájának örökségét.

A Gázolás esetében a szocialista realista korszak közelsége miatt mindez jóval explicitebb. A karakterek a termelési filmek sémáját követik: a csábító femme fatale a reakciósok körébe tartozik, áldozata, a fiatal bíró az ingadozó szerepét alakítja, a haladók oldalán pedig a bíró fönökét, egy joviális és humánus bölcs öregembert találunk. A reakciósok nem nélkülözik a túlzó, karikaturisztikus, sematikus vonásokat, a haladó alakja viszont kifejezetten visszafogott, míg az ingadozó valódi drámai karakter. Gertler Viktor filmje a szocialista realista konfliktus- és karakterséma ellenére tökéletesen megfelel a film noir müfaji és stiláris elvárásainak - de a tételt meg is fordíthatjuk: egy 1955-ös film noiron is átüt a direkt propagandisztikus ideológiai üzenet.

Harminc évvel később ez a kompromittáló hagyomány már halványul, de még mindig felismerhetö. A Dögkeselyü rutinos zsebtolvajainak, a két decens hölgynek ugyanis zavaros 56-os múltjuk van, vagyis a reakciósok csoportjába tartoznak. Mindez kevéssé hangsúlyozott, ám explicit motívuma a történetnek. A másik szocialista realizmusból megöröklött bünügyi motívum viszont már implicit, radikális társadalombírálatra nyújt alkalmat. A testületként ábrázolt nyomozók ugyanis nem folytatnak érdemi nyomozást az ügyben, sőt meggyanúsítják a föhőst, aki így kénytelen az önbíráskodás útjára lépni. András Ferenc ezzel a bünügyi filmek kompromittált motívumát a rendszer ellen fordítja, méghozzá a történet döntő, müfaji aspektusában (thriller). Ehhez társulnak a film további társadalomkritikus elemei a taxizni kénytelen értelmiségi hős gazdasági kiszolgáltatottságától a vagyonosok világán át a „fehérgalléros” vállalkozói bünözőig. Nem véletlen, hogy a korabeli kritikus a Dögkeselyü kapcsán a népszerü film nálunk elhomályosuló evidenciájára kénytelen utalni: „Pedig a tömegfilm feladója, vevője és üzenete - maga a társadalom. A tömegfilm-rendező a megszilárdult müfaji kereteket aktuális problémákkal tölti fel, $\mathrm{s}$ azokat a társadalmi értékeket és normákat, tiltásokat és preferenciákat önti formába, amelyeket ott és akkor a társadalmi tudat állapotára jellemzőek." Majd néhány ellenpélda felsorolása után a Dögkeselyüt a fenti leírásnak megfelelö filmként határozza meg: „A Dögkeselyü viszont a büntettet, a criment a maga társadalmiságában, szociologikumában bontja ki” (Réz 1982, 60).

A propagandisztikus ideológia szerint Magyarországon az államszocializmus korában a bün csak történelmileg, társadalmilag vagy politikailag motivált módon van jelen. Bünügyi filmek azonban ebben a korszakban is születnek. Mi ez, ha nem ellentmondás? A bünügyi film - és tágabb értelemben a népszerü filmkultúra - ellentmondása. 


\section{Irodalom}

Balogh Gyöngyi-Király Jenő. 2000. „, Csak egy nap a világ ... ”: A magyar film müfajés stílustörténete 1929-1936. Budapest: Magyar Filmintézet.

Bényei Tamás. 2000. Rejtélyes rend: A krimi, a metafizika és a posztmodern. Budapest: Akadémiai.

Király Jenő. 1981. Apropó western...: A magyar kalandfilm problémái. In Film és szórakozás, szerk. Király Jenő. 155-236. Budapest: MOKÉP-Magyar Filmtudományi Intézet és Filmarchívum.

Király Jenő. 1998. Mágikus mozi: Müfajok, mítoszok, archetípusok a filmkultúrában. Budapest: Korona.

Koltai Ágnes. 1986. A bün története: Krimi magyar módra. Filmvilág 29 (10): 10-13.

Kovács András Bálint. 1989. A „,szoft horror”: Populáris mítosz Magyarországon. Filmvilág 32 (9): 28-33.

Kovács András Bálint. 1995. Krém torta nélkül: A magyar film és a közönség. Filmvilág 38 (2): 4-5.

Lakatos Gabriella. 2013. A magyar félbünfilm: Bünügyi müfajok 1931 és 1944 között. Metropolis 17 (2): 50-66.

Mecseki Anett. Egy eltünt zsáner nyomában: A szocialista krimi http://magyar.film.hu/ filmtortenet/mufajok/egy-eltunt-zsaner-nyomaban-a-szocialista-krimi-mufajelemzes. html (2016. jan. 30.)

Pápai Zsolt-Varga Balázs. 2010. Hollywoodon innen és túl: Bevezető a magyar müfaji film összeállításhoz. Metropolis 14 (1): 8-22.

Réz András. 1982. Neophron percnopterus: András Ferenc: Dögkeselyü. Filmkultúra 18 (4): 59-63.

Réz András. 1984. Importált hősök: Észrevételek a magyar szórakoztató film jelen állapotáról. In Kortársunk a film, szerk. Dániel Ferenc. 257-267. Budapest: Múzsák Közmüvelődési Kiadó.

Vajdovich Györgyi. 2013. Ideológiai üzenet az 1939-1944 közötti magyar filmben: A magyar népi film. Metropolis 17 (2): 68-76.

Váradi Júlia-Kovács András Bálint. 1995. A Meseautó esélye: Beszélgetés Király Jenővel. Filmvilág 38 (1): 45-47.

\section{Filmográfia}

Apáthi Imre: Tüz (1948)

A Magyar Filmgyártó Nemzeti vállalat rendezői és dramaturgiai munkaközössége: Gyarmat a föld alatt (1951)

Máriássy Félix: Teljes gőzzel (1951) 
Gertler Viktor: Gázolás (1955)

Várkonyi Zoltán: Merénylet (1959)

Palásthy György: Mindenki ártatlan? (1961)

Fehér Imre: Húsz évre egymástól (1962)

Richard Thorpe: Az aranyfej (1963)

Gertler Viktor: Egy ember, aki nincs (1963)

Várkonyi Zoltán: Foto Háber (1963)

Palásthy György: Meztelen diplomata (1963)

Gertler Viktor: Özvegy menyasszonyok (1964)

Nádasy László: Fény a redőny mögött (1965)

Hintsch György: Kártyavár (1967)

Oláh Gábor: A múmia közbeszól (1967)

Bácskai Lauró István: A hamis Izabella (1968)

Szemes Mihály: Az alvilág professzora (1969)

Révész György: Az oroszlán ugrani készül (1969)

Bán Róbert: A gyilkos a házban van (1970)

Szőnyi G. Sándor: Jó estét nyár, jó estét szerelem (1971)

Várkonyi Zoltán: Emberrablás magyar módra (1972)

Fejér Tamás: Hekus lettem (1972)

Keleti Márton: Fuss, hogy utolérjenek (1972)

Magyar József: Illatos út a semmibe (1973)

Várkonyi Zoltán: Ártatlan gyilkosok (1973)

Mihályfi Imre: A közös bün (1977)

Mészáros Gyula: A néma dosszié (1977)

Bán Róbert: Dóra jelenti (1978)

Szinetár Miklós: Az erőd (1978)

Dobray György: Az áldozat (1979)

Szalkai Sándor: Kojak Budapesten (1980)

Mészáros Gyula: A Pogány Madonna (1980)

Bacsó Péter: A svéd, akinek nyoma veszett (1980)

Fábry Péter: Nyom nélkül (1981)

Szőnyi G. Sándor: Csak semmi pánik (1982)

András Ferenc: Dögkeselyü (1982)

Simó Sándor: Viadukt (1982) 
Bujtor István: Az elvarázsolt dollár (1985)

Gazdag Gyula: Túsztörténet (1988)

Tímár Péter: Mielött befejezi röptét a denevér (1988)

Bujtor István: Hamis a baba (1991)

\section{POPULAR FILM CULTURE IN THE ERA OF STATE SOCIALISM} An example of Hungarian crime films

Hungarian film history after 1945 is usually defined within the paradigm of authors' films films.. The status of popular or genre film production during the era of state socialism was controversial in the period 1948-1989, and this influence can still be felt today. The paper, after giving a general review of the status of popular film culture, studies the roots and consequences of this discrepency on the example of a corpus of forty items of crime films. All this can partly enrich the description of the film history of the period, and partly aid the interpretation of contemporary Hungarian film art in which the popular film culture and within it the position of crime films still remains controversial in spite of the social and political set of conditions that should be met.

Keywords: Hungarian film history, popular film culture, era of state socialism, genre of crime films.

\section{POPULARNA FILMSKA KULTURA U DOBA DRŽAVNOG SOCIJALIZMA}

\section{Na primeru mađarskog kriminalističkog filma}

Period mađarske istorije filma posle 1945. godine se prvenstveno definiše kao paradigma autorskog filma. Položaj popularne ili žanrovske filmske produkcije u periodu državnog socijalizma između 1948. i 1989. je kontradiktoran i taj uticaj se oseća sve do danas. Studija nakon opšteg pregleda položaja popularne filmske kulture razloge i posledice te kontradiktornosti analizira na primeru korpusa kriminalističkih filmova koji se sastoji od četrdesetak stavki. Sve to delimično može da obogati opis istorije filma tog razdoblja, a delimično može da potpomogne u tumačenju položaja savremene mađarske filmske umetnosti, u kojoj je položaj popularne filmske kulture i u sklopu toga kriminalističkog filma - uprkos promenjenim društvenim i političkim okolnostima posle 1989. godine - i dalje kontradiktoran.

Ključne reči: istorija mađarskog filma, popularna filmska kultura, doba državnog socijalizma, žanr kriminalističkog filma. 